\title{
COMPARTIMENTAÇÃO DO COMPLEXO CAMPOS GERAIS ENTRE CARMO DO RIO CLARO E FORTALEZA DE MINAS, MG.
}

G.A.J.Szabó

O Complexo Campos Gerais (CCG), tal como proposto pelo Relatório Final do Projeto Sapucal (CPRM; CAVALCANTE et al., 1979), corresponde a uma unidade heterogênea, artificial, criada por conveniência no decorrer de levantamentos geológicos em escala regional. Posteriormente, uma série de trabalhos conduzidos em áreas consideradas como pertencentes ao CCG demonstraram uma compartimentação em unidades internamente coerentes, individualizáveis, e em parte correlacionáveis à outras unidades encontradas ao redor do CCG (eg. Complexo Barbacena a leste, Grupos Andrelândia e Sáo João del Rei a sudeste). A parte norte do CCG corresponde a terrenos tipo granito-greenstone-migmatificos fortemente modificados por intensos processos tectonotermais que marcaram a evolução da borda sul do Cráton do São Francisco. Apesar do forte cisalhamento e das remobilizações anatéticas ou processos migmatticos sensu latu atuantes em escala variável em diferentes porções deste domínio, foi possivel reconhecer componentes originais, menos modificados, das associações litológicas antecessoras do atual conjunto de ortognaisses milonfticọs/anatéticos/migmatticos. Dentre estes componentes, destacam-se as rochas metaultramáficas identificadas como integrantes de uma pretérita sufte vulcânica komatiftica, não raro com texturas reliquiares preservadas e tipicamente com BIF associadas, que comportam ocorrências de sulfetos maciços de Ni-Cu tidas como de origem vulcanogênica. Também merecem destaque os núcleos de tonalitos porfiróides em meio aos ortognaisses granodiorticos follados/cisalhados e parclalmente remobilizados, que foram datados, através de uma errócrona $\mathrm{Rb} / \mathrm{Sr}$, em caráter preliminar, em 2,8 Ga. (AKIMOTO \& TEIXEIRA, 1988; Rel.Bolsa Inic.Cient.CNPq, CPGeo, Instituto de Geociências, USP), enquanto ortognaisses/granitóides próximos apresentaram idades Rb/Sr de 1,8

Departamento de Mineralogia e Petrologia, Instituto de Geociéncais, USP. 
Ga. (CHOUDHURI et al., inédito). Estes tonalitos porfiróides, denominados informalmente "tonalitos Dondó", diferem de maneira evidente de tonalitos não porfiróides, cinza-esverdeados e de aspecto geral mais homogêneo e quase-maciço, denominados tipo "Fazenda das Almas", que possuem ocorrência mais individualizada $\theta$ extensa, exibindo feições anatéticas apenas em alguns locais.

Os "tonalitos Dondó" ocorrem a sul de Alpinópolis, a norte de um forte alinhamento estrutural WNW marcado pelas encostas sul das serras do Dondó e do Quilombo, que desaparece por balxo do conjunto metasedimentar alóctone dos Grupos Araxá-Canastra a norte e é tido como uma falha mais recente (brasiliana?), implantada mimeticamente sobre direções estruturais mais antigas, de faixas de cisalhamento (arqueanas-transamazônicas?); já os tonalitos "Fazenda das Almas" afloram a sul deste alinhamento, e se prolongam para oeste, em direção a Fortaleza de Minas. Por fim, vale destacar os diversos conjuntos de anfibolitos que ocorrem tanto em meio aos ortognaisses como intercalados à sufte metaultramáfica, e que, até o momento, foram identificados como representantes de pelo menos três gerações de rochas básicas: uma correspondente a possiveis vulcânicas máficas intercaladas aos komatiftos, outra correspondente a diques instalados após o desenvolvimento da follação principal nas rochas metaultramáficas e antes de uma importante fase de cisalhamnto de alto ângulo nos ortognaisses circunvizinhos, e a terceira, correspondente a diques de colocação tardia na evolução da área, pouco ou nada metamorfoseados e/ou deformados.

Pretende-se prosseguir com o estudo destes componentes do domínio norte do CCG, na faixa entre Carmo do Rio Claro e Fortaleza de Minas, a sul de Alpinópolis, procurando retratar melhor este domínio no que diz respeito aos seus constituintes litológicos e sua evolução, de modo a resgatar um quadro tectono-estratigráfico mais claro para esta região controversa. 